\title{
Trastuzumab Mechanism of Action; 20 Years of Research to Unravel a Dilemma
}

\author{
Hamid Maadi ${ }^{1}$, Mohammad Hasan Soheilifar ${ }^{2}$, Won-Shik Choi ${ }^{1}$, Abdolvahab Moshtaghian ${ }^{3,4}$ \\ and Zhixiang Wang ${ }^{5, *(D)}$
}

1 Department of Oncology, Cross Cancer Institute, University of Alberta, Edmonton, AB T6G 1Z2, Canada; hmaadi@ualberta.ca (H.M.); wonshik@ualberta.ca (W.-S.C.)

2 Department of Medical Laser, Medical Laser Research Center, Yara Institute, ACECR, Tehran 1315795613, Iran; h.soheilifar@edu.umsha.ac.ir

3 Department of Molecular and Cell Biology, Faculty of Basic Sciences, University of Mazandaran, Babolsar 4741695447, Iran; vahabmoshtagh@semums.ac.ir

4 Deputy of Research and Technology, Semnan University of Medical Sciences, Semnan 3514799442, Iran

5 Department of Medical Genetics and Signal, Transduction Research Group, Faculty of Medicine and Dentistry, University of Alberta, Edmonton, AB T6G 2H7, Canada

* Correspondence: zhixiang.wang@ualberta.ca

Citation: Maadi, H.; Soheilifar, M.H.; Choi, W.-S.; Moshtaghian, A.;

Wang, Z. Trastuzumab Mechanism of Action; 20 Years of Research to Unravel a Dilemma. Cancers 2021, 13 3540. https://doi.org/10.3390/ cancers 13143540

Academic Editors: Jonas Cicenas and Kylie Gorringe

Received: 6 May 2021

Accepted: 12 July 2021

Published: 15 July 2021

Publisher's Note: MDPI stays neutral with regard to jurisdictional claims in published maps and institutional affiliations.

Copyright: (c) 2021 by the authors. Licensee MDPI, Basel, Switzerland. This article is an open access article distributed under the terms and conditions of the Creative Commons Attribution (CC BY) license (https:// creativecommons.org/licenses/by/ $4.0 /)$.
Simple Summary: Overexpression of HER2 receptors have been identified in various types of cancer including breast cancer and ovarian cancer. HER2 overexpression is generally associated with poor clinical outcomes in patients with HER2-positve tumors. Trastuzumab, an antibody specifically targeting HER2 receptors, showed promising clinical benefits for patients with HER2-positive tumors. Studies show that trastuzumab suppresses HER2 receptors' oncogenic functions in HER2-postive tumors. Moreover, trastuzumab has been shown to provoke immune responses against the HER2amplified tumors.

Abstract: Trastuzumab as a first HER2-targeted therapy for the treatment of HER2-positive breast cancer patients was introduced in 1998. Although trastuzumab has opened a new avenue to treat patients with HER2-positive breast cancer and other types of cancer, some patients are not responsive or become resistant to this treatment. So far, several mechanisms have been suggested for the mode of action of trastuzumab; however, the findings regarding these mechanisms are controversial. In this review, we aimed to provide a detailed insight into the various mechanisms of action of trastuzumab.

Keywords: trastuzumab; breast cancer; HER2; PI3K/AKT pathway; MAPK pathway

\section{Introduction}

HER2 overexpression in approximately $20-30 \%$ of breast cancer (BC) patients has motivated researchers for years to find a decent drug to specifically target HER2. A humanized monoclonal antibody named trastuzumab (Herceptin ${ }^{\circledR}$ ), which targets the extracellular domain of HER2, was developed. Since the approval of trastuzumab, many investigations have been carried out to unravel the trastuzumab mechanism of action and find an appropriate combination therapy to enhance the treatment efficacy. In this review, we aimed to shine the light on the various mechanisms through which trastuzumab exerts its anti-tumoral effects.

\section{From Characterization of HER2 to Developing Trastuzumab}

In 1984, Schechter et al. isolated a gene from ethylnitrosourea-induced rat neuro/glioblastomas and confirmed the ability of this gene to transform the NIH3T3 cells [1]. This gene, which is named ' $n e u^{\prime}$, was later shown to encode a protein with $185 \mathrm{kDa}$ molecular weight [1]. One year later, Coussens et al. identified and characterized a gene located at the human q21 region of chromosome 17 which was homologous to the rat neu gene [2]. 
Due to the significant similarities in the protein sequence between the EGFR (HER1) and the product of the neu gene, it was named HER2 and suggested to play a role as a kinase receptor at the cell surface. In 1986, Drebin et al. demonstrated the tumorigenic potential of NIH3T3 cells, when transfected with the HER2 gene in vivo [3]. They also showed that treating the mice with an antibody against the neu gene product (anti-HER2 antibody) significantly suppresses tumor growth. The oncogenic function of HER2 was also confirmed by another research group about a year later [4]. In 1987, Slamon et al. found that the HER2 gene is amplified in about $30 \%$ of $\mathrm{BC}$ tumors, and this amplification is significantly correlated with poor prognosis in BC patients [5]. In 1989, Hudziak et al. isolated a monoclonal antibody named "4D5", which has a high specificity toward HER2, from mice exposed to this receptor and showed its antiproliferative effects against SKBR3 HER2-positive BC cells [6]. In 1992, Carter et al. humanized the 4D5 monoclonal antibody which made it suitable for further clinical evaluation [7]. This antibody, which was named "Trastuzumab", showed significant clinical benefits toward patients with HER2-positive BC and increased the efficacy of conventional chemotherapies [8]. Finally, trastuzumab was approved in the USA and Europe in 1998 and 2000, respectively [9,10]. The key findings related to trastuzumab history are summarized in Figure 1. After demonstrating the clinical benefits of trastuzumab, many studies were carried out in an attempt to unravel the mechanisms of action of trastuzumab. In this review, we discuss different mechanisms of action proposed for trastuzumab.

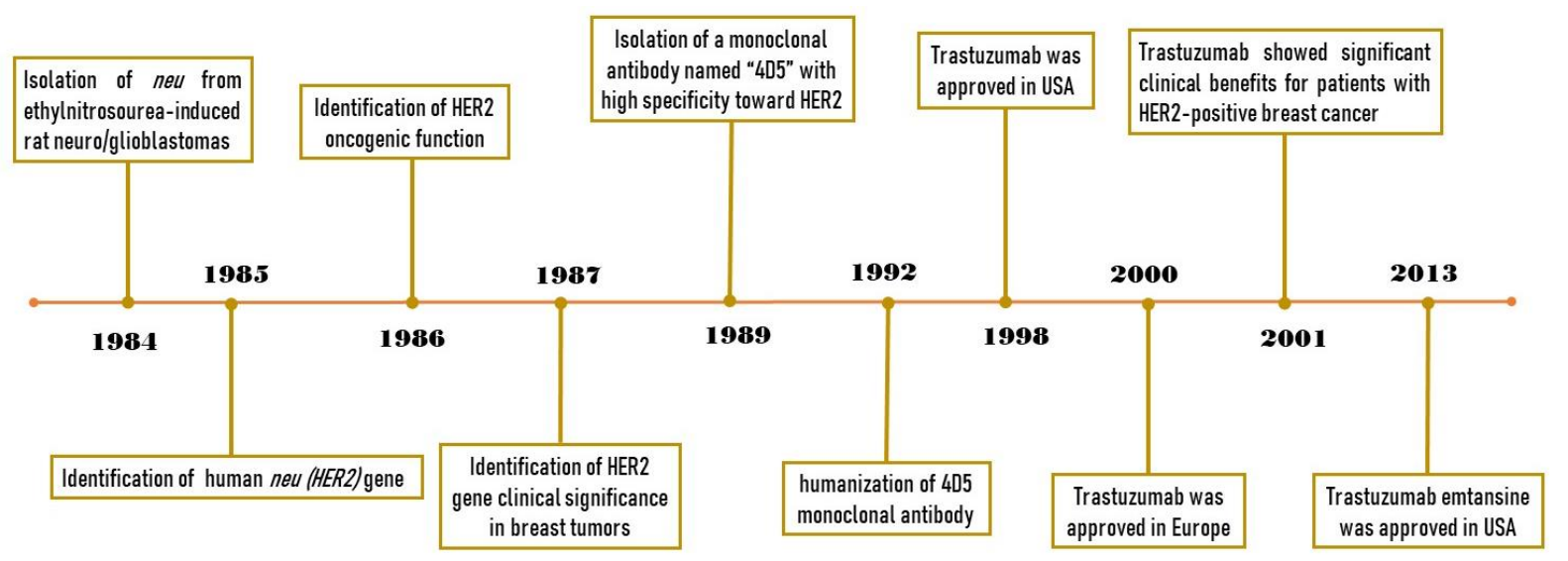

Figure 1. Timeline of trastuzumab history, from HER2 identification to demonstrating the clinical benefits of trastuzumab.

\section{HER2 Signaling}

The ErbB receptor tyrosine kinase 2 (ErbB2 or HER2) belongs to the ErbB (HER) family of receptor tyrosine kinases along with three other members, including epithelial growth factor receptor (EGFR), ErbB3 (HER3), and ErbB4 (HER4) [11]. Generally, these receptors consist of three main domains: (1) the extracellular domain that contains the four subdomains that mediate HER receptor ligand-dependent or -independent dimerization, (2) transmembrane domain that connects extracellular and cytoplasmic domains, and (3) the C-terminal cytoplasmic domain that contains tyrosine kinase and regulatory subdomains [12]. Upon the binding of HER-specific ligands to HER receptors, these receptors form homo- or heterodimers. Subsequently, certain tyrosine residues in cytoplasmic domains are auto-phosphorylated or trans-phosphorylated to activate several intracellular signaling pathways $[13,14]$. Structural analysis revealed an open conformation for HER2 extracellular domain similar to a ligand-activated state of other HER receptors, suggesting that these receptors form homo- and heterodimers independent of ligands [15]. Until now, no HER2-specific ligand has been identified, consistent with what was found in the structural analysis. Therefore, HER2 is a preferred binding partner in HER receptors' dimerization. In pathological conditions, the overexpression of HER2 facilitates the ligandindependent HER2 homo- and heterodimerization and activates multiple downstream 
signaling pathways involved in the malignant properties of cancer cells [16]. Therefore, the inhibition of HER2 dimerization plays an important role in the suppression of HER2mediated cell signaling and tumor growth.

Phosphorylation of HER2 at specific phosphorylation residues provides docking sites for several downstream effectors, including growth factor receptor-bound protein 2 (Grb2) and Src homology 2 domain containing transforming protein (Shc), which play an important role in regulating the mitogen-activated protein kinase (MAPK) signaling pathway $[17,18]$. HER2 has been shown to activate the phosphatidylinositol 3-kinase $(\mathrm{PI} 3 \mathrm{~K})$ / protein kinase $\mathrm{B}$ (PKB/AKT) signaling pathway both directly and indirectly. Heterodimerization of HER2 with HER3 activates the PI3K/Akt signaling pathway through the phosphorylation of HER3 receptors at multiple tyrosine residues [19]. It has been shown that the phosphorylation of HER3 provides several binding sites for a p85 subunit of PI3K and significantly activates the PI3K/AKT signaling pathway $[19,20]$. Furthermore, HER2 has been shown to indirectly activate the PI3K/AKT signaling through Src-mediated inhibition of phosphatase and tensin homolog (PTEN) activity [21]. On the other hand, Ruiz-Saenz et al. have revealed that the p85 regulatory subunit of PI3K directly binds to HER2 at tyrosine 1139, which suggest that HER2 directly activates the PI3K/AKT pathway [22]. Altogether, in various types of cancers, HER2 plays a critical role in activating MAPK and PI3K/Akt signaling pathways. The detail of these signaling pathways is illustrated in Figure 2.

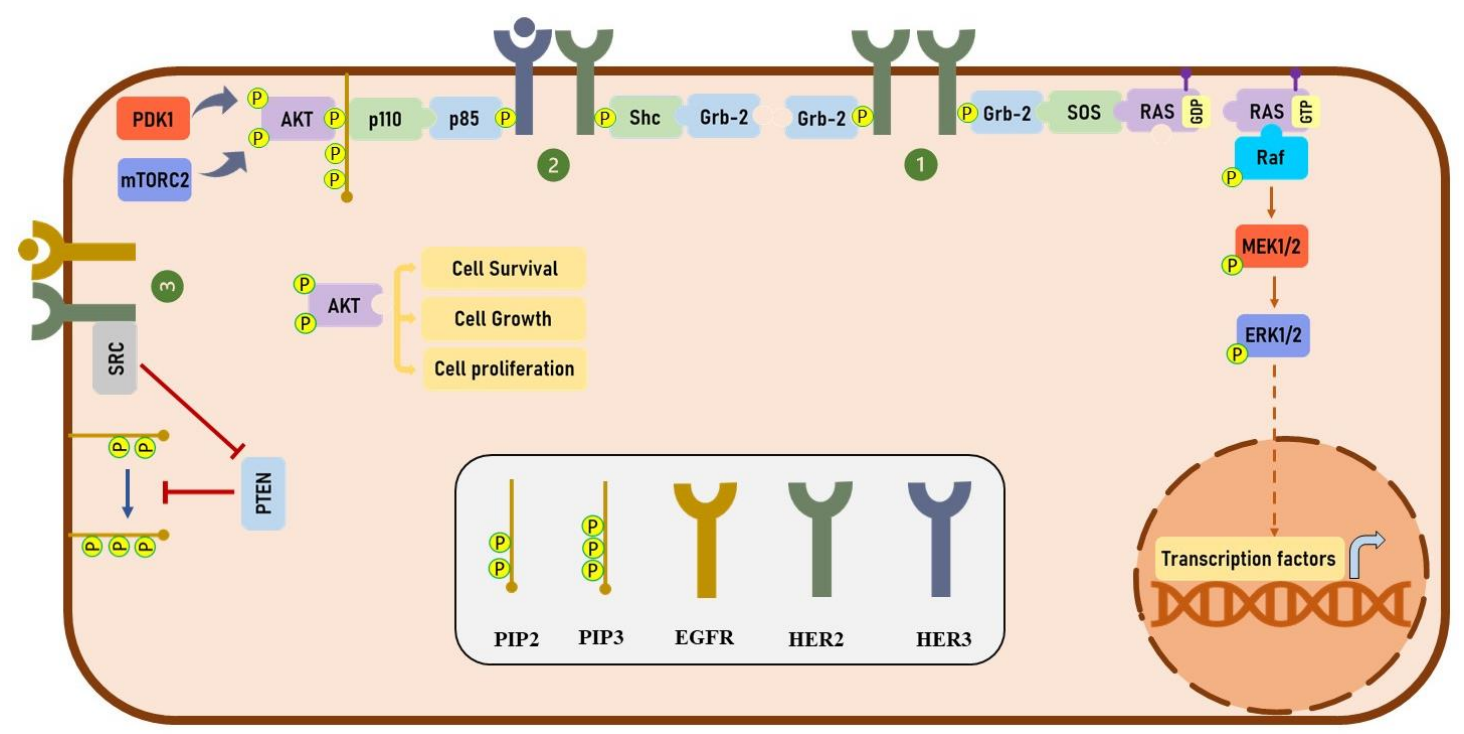

Figure 2. HER2-mediated downstream signaling pathway. (1) HER2-mediated activation of MAPK signaling pathway. Upon homodimerization of HER2 receptors, these receptors are phosphorylated at different phosphorylation sites. Phosphorylation of HER2 provides binding sites for Grb-2 proteins which bind to SOS with GEF activity. SOS then activates RAS by replacing the GDP with GTP. The activated RAS phosphorylates Raf, and Raf phosphorylates MEK. Finally, ERK is phosphorylated and activated by MEK which enables this protein to enter the nucleus and activate the transcription of genes involved in various cellular processes. (2) HER2-mediated activation of PI3K/AKT signaling pathway: upon the binding of HER3-specific ligands, such as heregulin (HRG) to HER3, the HER2-HER3 heterodimers are formed and HER2 phosphorylates HER3 at different tyrosine residues. The phosphorylated HER3 provides docking sites for p85 subunit of PI3K. The fully activated PI3K complex is generated by binding of p110 subunit of PI3K to p 85 which is able to produce PIP3 via phosphorylating the PIP2. AKT binds to PIP3 and is phosphorylated by PDK1 and mTORC2. Phosphorylation of AKT at both threonine and serin phosphorylation sites significantly increases its catalytic activity which regulates the function of various proteins involved in several cellular processes. (3) HER2-mediated inhibition of PTEN activity: SRC binds to HER2 receptors and inhibits the activity of PTEN via mediating the phosphorylation of this enzyme. As a phosphatase, PTEN dephosphorylates PIP3 and therefore inhibits the binding of AKT to PIP3. 


\section{Trastuzumab and HER2 Dimerization}

Trastuzumab has been shown to bind three distinct regions of domain IV of the HER2 extracellular domain through electrostatic and hydrophobic bindings $[15,23]$. Initially, it was speculated that trastuzumab inhibits tumor growth through blocking HER2 dimerization with other HER receptors. However, studies reported controversial results regarding the effects of trastuzumab on HER2 homo- and heterodimerization. Generally, the effects of trastuzumab on HER2 dimerization are evaluated in two different conditions: (1) the effect of trastuzumab on ligand-dependent HER2 heterodimerization, and (2) the effect of trastuzumab on ligand-independent HER2 homo- and heterodimerization. In the presence of HER-specific ligands, trastuzumab has no significant effects on HER2 heterodimerization $[16,23,24]$. On the other hand, findings about the effect of trastuzumab on ligand-independent HER2 heterodimerization are remained controversial. For instance, Gaborit et al. demonstrated that trastuzumab significantly blocks EGFR-HER2 heterodimerization in the SKOV-3 HER2-positive ovarian cancer cell line using a Fluorescence Resonance Energy Transfer (FRET)-based method [25]. On the contrary, Diermeier et al. showed that trastuzumab is unable to suppress the EGFR-HER2 heterodimerization in HER2-positive BC cell lines, BT474 and SKBR3, using a similar approach [16]. Using a reversible cross-linker, Junttila et al. showed that trastuzumab disrupts ligandindependent heterodimer formation while ligand-dependent heterodimerization remains unaffected [24]. To assess the effect of trastuzumab on HER2 homodimerization, we used the Chinese hamster ovary $(\mathrm{CHO})$ cells overexpressing human HER2 [26]. $\mathrm{CHO}$ cells have been shown to have little to no expression of all HER receptors, making it a good model to study homodimerization $[27,28]$. Surprisingly, our results showed that trastuzumab induces HER2 homodimerization in a dose- and time-dependent manner [26]. These results are consistent with previous reports showing enhanced HER2 homodimerization upon trastuzumab treatment in HER2-positive BC cell lines, SKBR3 and BT474 [16]. It is yet to be determined how trastuzumab concurrently induces HER2 homodimerization and inhibits ligand-independent HER2 heterodimerization. Taken together, these findings suggest that trastuzumab has limited effects on HER2 homo- and heterodimerization.

\section{Trastuzumab and HER Phosphorylation}

Using the $\mathrm{CHO}$ cells overexpressing EGFR, HER2, or HER3, we showed that trastuzumab specifically binds to HER2 and does not bind to EGFR and HER3 [26]. Therefore, trastuzumab potentially affects the HER2-mediated signaling directly and other members of HER familymediated signaling indirectly. Contrary to the initial expectation of a possible inhibitory role of trastuzumab on HER2 phosphorylation, several studies have shown that trastuzumab induces HER2 phosphorylation [16,29-32]. So far, three mechanisms have been suggested for increasing the phosphorylation of HER2 by trastuzumab. First, as discussed, trastuzumab increases the HER2 homodimerization [26]. Second, trastuzumab induces tyrosine kinase activity of HER2, and hence increases the phosphorylation of HER2 upon homodimerization [29]. Third, trastuzumab increases the HERs-specific ligand production to activate other HER receptors through the upregulation of ADAM17 [32]. ADAM proteases play a significant role in generating HER ligands from pro-HER ligands [33]. Increased HERsspecific ligand production leads to ligand-dependent HER2 heterodimerization, thereby inducing HER2 phosphorylation [32]. However, as discussed earlier, the majority of studies found that trastuzumab had little to no effect on ligand-dependent HER2 heterodimerization and phosphorylation. It is worth mentioning that higher phosphorylation of HER2 at tyrosine 1248 is positively correlated with good prognosis in patients with HER2-positive BCs upon trastuzumab therapy [29]. It is yet to be exactly determined how trastuzumab concurrently induces HER2 phosphorylation and inhibits cancerous features of HER2positive BC cells.

Although the effect of trastuzumab on EGFR and HER4 phosphorylation is not wellstudied, evidence supporting the inhibitory role of trastuzumab on HER3 phosphorylation is quite robust $[24,29,32]$. Moreover, it has been shown that trastuzumab can induce HER3 
degradation [29]. Altogether, current findings suggest that trastuzumab increases HER2 phosphorylation while suppressing HER3 phosphorylation.

\section{Trastuzumab and HER2 Endocytosis and Degradation}

The effects of trastuzumab on inducing the HER2 endocytosis and degradation are controversial. Although some studies show the downregulation of HER2 upon trastuzumab treatment [32,34-37], others show no effect [31,38,39]. Generally, studies have shown that the long-term treatment of trastuzumab downregulates HER2 but did not provide a clear mechanism on how trastuzumab downregulates HER2. Of note, a few studies have shown that trastuzumab decreases the expression of other HER receptors including HER3 and EGFR $[29,35,36]$.

The effect of trastuzumab on HER2 endocytosis has been well studied by Austin et al. [38]. They showed that HER2 receptors are frequently internalized and recycled to the plasma membrane and trastuzumab had no effects on this cycle. Their extensive results have revealed that, although trastuzumab is detected in internalized vesicles a few hours after the treatment of the BC cells, these vesicles are mainly recycling endosomes rather than degrading ones. The majority of trastuzumab, along with HER2 receptors, was recycled to the plasma membrane in a short period of time. Using the same BC cell lines, Dokmanovic et al. detected trastuzumab internalization and HER2 degradation after treating the cells for four days [34]. Intriguingly, the localization of internalized trastuzumab bound to HER2 in early endosomes was shown in both studies. In addition, in vitro experiments unraveled the negative correlation between caveolin-1 (CAV1) and HER2 expression [40]. It has been shown that the suppression of CAV1-mediated HER2 endocytosis stabilizes HER2 at cell membrane and increases HER2-trastuzumab complex formation in HER2-positive tumors, which ultimately enhances trastuzumab-induced antibody-dependent cell-mediated cytotoxicity (ADCC) [40]. Furthermore, Scaltriti et al. showed that HER2 ubiquitination and degradation can be elevated after trastuzumab treatment [37]. Taken together, our knowledge about the possible role of trastuzumab on HER2 endocytosis is limited. More studies should be carried out to unravel the molecular mechanism(s) through which trastuzumab modulates HER2 endocytosis and degradation.

\section{Trastuzumab and the MAPK Signaling Pathway}

The MAPK pathway, one of the well-studied signaling pathways, plays an important role in various cellular processes, such as cell proliferation, differentiation, apoptosis, migration, and stress responses [41,42]. In addition, this pathway is highly activated in different types of cancer [43,44]. Generally, four different MAPK downstream effectors, including extracellular signal-regulated kinase1/2 (ERK1/2), ERK5, p38 MAPK, and c-JUN $\mathrm{N}$-terminal kinase (JNK), are activated in response to different stimuli [42]. The activation of RTKs by extracellular ligands such as epidermal growth factor (EGF) activates the ERK1/2 and ERK5; however, two other effectors (p38 MAPK and JNK) are generally activated by cellular and environmental stresses [45,46]. Moreover, it has been shown that leukemia inhibitory factor (LIF) and the signal transducer and activator of transcription-3 (STAT-3) activates mitogen-activated protein kinase 5 (MEK5), which subsequently activates ERK5 in normal and cancer cells [47-49]. In the EGFR signaling pathway, the binding of HER-specific ligands to HERs induce receptors' homo- and heterodimerization and phosphorylation $[13,14]$. Phosphorylation of HERs at specific residues provides docking sites for various adaptor proteins including Grb-2 $[17,18]$. Grb-2 binds to a protein with guanine nucleotide exchange factor (GEF) activity named Son of Sevenless (SOS), which in turn activates the Rat Sarcoma viral proto-oncogene (RAS) protein by replacing the guanosine triphosphate (GTP) with guanosine diphosphate (GDP) [41,50]. The activation of RAS mediates the activation and phosphorylation of a cascade of downstream serine/threonine kinases, which ultimately ends with the phosphorylation of ERK1/2 protein [50]. The phosphorylated and dimerized ERK1/2 proteins are translocated into the nucleus to regulate the function of transcription factors playing pivotal roles in various 
cellular processes [51]. In HER2-positive BC, due to the overexpression of HER2 receptors, the formation of HER2 homodimers, and therefore HER2 phosphorylation, are significantly elevated. Increased phosphorylation of HER2 receptors provides several binding sites for different adaptor proteins involved in regulation of MAPK signaling pathway [17,18], and hence hyperactivates this signaling pathway in HER2-positive BC tumors. Therefore, trastuzumab potentially affects the MAPK pathway through intervening with the HER2 receptors' normal functions.

Different studies have suggested both inhibitory and activatory roles of trastuzumab on MAPK signaling. However, the experimental conditions are not consistent in these studies. ERK1/2 phosphorylation was increased when cells are exposed to short term treatment of trastuzumab [29,31,32]. For instance, Bagnato et al. have shown that treatment of SKBR3 HER2-positive BC cells with trastuzumab for 2 minutes significantly increases ERK1/2 phosphorylation [31]. Although several studies have indicated that trastuzumab inhibits the MAPK signaling pathway [23,52-57], the findings suggest that the effect of trastuzumab on MAPK signaling can be altered by some conditions. Watanabe et al. have demonstrated that, even though trastuzumab inhibits ERK1/2 phosphorylation in SKBR3 HER2-positive BC cells, it does not have any effect on ERK1/2 phosphorylation in BT474 HER2-positive BC cells [58], suggesting the cell line-specific effects of trastuzumab on MAPK signaling. Using MCF10A human breast epithelial cells stably transfected with a plasmid containing chimeric human HER2 and a FK506-binding protein (FKBP), Ghosh et al. tested MAPK activation when cells are cultured with three different molecules: (1) transforming growth factor $\alpha$ (TGF $\alpha$ ) for HER2-EGFR heterodimerization, (2) heregulin for HER2-HER3 heterodimers, and (3) AP1510, an artificial ligand to homodimerize HER2FKBP proteins [54]. They showed that trastuzumab induces disassociation of Shc from HER2, and therefore decreases the ERK1/2 phosphorylation in presence of AP150, but not TGF $\alpha$ and heregulin. This suggests that trastuzumab specifically inhibits HER2 homodimermediated ERK1/2 phosphorylation, while remaining ineffective for HER2 heterodimermediated ERK1/2 phosphorylation. Interestingly, it has been shown that even using the MEK inhibitors which suppresses the ERK1/2 phosphorylation completely does not reduce the viability of trastuzumab-sensitive BC cell lines [24]. This finding indicates that if trastuzumab has any inhibitory role on the MAPK signaling pathway, it will not have significant effects on the proliferation ability of the cells.

\section{Trastuzumab and PI3K/AKT Signaling Pathway}

PI3K/AKT signaling is usually highly activated in various types of cancer [59,60]. This pathway regulates different cellular processes including cell growth, survival, and proliferation [61]. The EGFR signaling pathway activates PI3K/AKT signaling in response to the external stimuli [14]. Among the different members of EGF receptor family, HER3 plays a central role in activating PI3K/AKT signaling by providing several binding sites for $\mathrm{p} 85$ subunit of PI3K after being phosphorylated via other HER receptors [17,22,62]. In HER2positive $\mathrm{BC}$ due to the overexpression of HER2, the ligand-dependent or -independent HER2-HER3 heterodimer can be easily formed to activate the PI3K/AKT signaling [24]. Indeed, the HER2-HER3 heterodimer has a more oncogenic role in comparison with the other dimers of HER [52,63]. Generally, upon the binding of the ligand to HER3, these receptors form a heterodimer with other members of the HER family, such as HER2 [19]. The HER3 receptors are phosphorylated by HER2 at different phosphorylation sites to provide several docking sites for the p85 subunit of PI3K $[19,20]$. After the binding of p85 to HER3, p110 binds to p85 to form the PI3K complex, which then phosphorylates phosphatidylinositol bisphosphate (PIP2) and produces phosphatidylinositol triphosphate (PIP3) $[59,64]$. AKT proteins bind to PIP3 through its N-terminal pleckstrin homology $(\mathrm{PH})$ domain and are phosphorylated at threonine and serin residues via phosphoinositidedependent kinase 1 (PDK1) and mammalian target of rapamycin complex (mTORC2), respectively [59]. Phosphorylation of AKT at both threonine and serine amino acids significantly increases its catalytic activity [65]. It is worth mentioning that phosphatase and 
tensin homolog (PTEN) as a main inhibitor of the PI3K/AKT pathway suppresses AKT phosphorylation by dephosphorylating PIP3, and therefore preventing the association of AKT and PIP3 [66].

Extensive studies have shown that trastuzumab suppresses AKT phosphorylation at both threonine and serine sites [21,23,24,29,52,53,56-58,67]. Since HER3 has been wellimplicated in the activation of the PI3K/AKT pathway, many groups have studied the effects of trastuzumab on HER2-HER3 heterodimerization and HER3 phosphorylation. As discussed earlier, several studies have demonstrated that trastuzumab suppresses HER3 phosphorylation $[24,29,32,52]$. On the other hand, our unpublished data, as well as the results published by the others [21,52], have shown that $1 \mathrm{~h}$ of trastuzumab treatment in trastuzumab-sensitive BC cell lines does not have any inhibitory effects on HER3 phosphorylation and PI3K activity; however, it drastically reduces the AKT phosphorylation. It seems that this rapid reduction of AKT phosphorylation is through a pathway independent of the PI3K activity and HER2-mediated HER3 phosphorylation. Nagata et al. have found that the short-term treatment of BC cells with trastuzumab reduces the PTEN phosphorylation, and hence induces the PTEN phosphatase activity by increasing the localization of this protein to the cellular membrane [21]. Indeed, patients with PTEN-loss breast tumors are more resistant to trastuzumab compared to BC patients with normal PTEN activity [21]. Interestingly, they also showed that trastuzumab dissociates Src from HER2, and consequently reduces the Src phosphorylation and kinase activity [21]. It has been demonstrated that Src increases the AKT phosphorylation by downregulating the PTEN activity [68]. Taken together, studies suggest that the inhibition of the PI3K/AKT signaling pathway is one of the main mechanisms of action of trastuzumab which is mediated by either the inhibition of HER3 phosphorylation or the activation of PTEN.

\section{Trastuzumab and Cell Cycle Arrest}

The cell cycle consists of four phases, including G0/G1, S, G2, and M phases, which are tightly regulated by several signaling pathways [69]. Complexes of cyclin-dependent kinases (CDKs) and cyclins promote cell cycle progression which are activated and inhibited by mitogenic signals and cell cycle inhibitors, respectively [69]. The cell cycle is usually arrested at the G0 phase and during the G1 phase, cells grow and are prepared to enter the $S$ phase if necessary [70]. Stimulation of the cells with mitogenic stimuli activates signaling pathways regulating CDK4 or CDK6 activation [69]. Generally, the binding of CDK4/ 6 to Cyclin D mediates the transition of the cell cycle from the G0/G1 phase into the $\mathrm{S}$ phase through inhibiting the $\mathrm{p} 21^{\mathrm{CIP} 1}$ and $\mathrm{p} 27^{\mathrm{KIP} 1}$ function as main inhibitors of CDKs [71]. Moreover, the phosphorylation of the retinoblastoma (RB) protein by the cyclin D-CDK4 / 6 complex blocks the association of RB and E2F transcription factor, which leads to the activation of E2F-modulated transcription of genes necessary for the entry of the cells into the $S$ phase of the cell cycle, wherein the DNA strands are replicated [71,72].

In the nucleus, p27 ${ }^{\mathrm{KIP} 1}$ binds to the cyclin E-CDK2 complex and represses cell cycle progression from the G1 phase to the S phase [73]. Phosphorylation of $\mathrm{p} 27^{\mathrm{KIP} 1}$ at threonine 187 increases its degradation [74]; however, serine 10 phosphorylation stabilizes the protein [75]. Several studies have revealed that trastuzumab arrests the BC cell cycle at the G0/G1 phase through activating the p27 ${ }^{\mathrm{KIP} 1}$ function $[30,52,55,76]$. Furthermore, Le et al. have shown that trastuzumab induces and reduces the phosphorylation of $\mathrm{p} 27^{\mathrm{KIP} 1}$ at serin 10 and threonine 187 phosphorylation sites, respectively [76]. Of note, trastuzumab not only elevates the protein expression of $\mathrm{p} 27^{\mathrm{KIP} 1}$ possibly through the inhibition of the protein degradation, but also increases the nuclear localization of this protein in BC cells [52]. Findings suggest that trastuzumab reactivates the $\mathrm{p} 27^{\mathrm{KIP} 1}$ function and arrests the cell cycle at the G0/G1 phase via inhibition of AKT phosphorylation [52]. Indeed, AKT mediates the phosphorylation of $\mathrm{p} 27^{\mathrm{KIP} 1}$ at threonine 198 , which results in the elevation of cytoplasmic localization of $\mathrm{p} 27^{\mathrm{KIP} 1}[77,78]$. The phosphorylation of $\mathrm{p} 27^{\mathrm{KIP} 1}$ at this region has been shown to be inhibited upon the treatment of the BC cells with trastuzumab [30]. Moreover, treatment of BT474 BC cells with LY294002, a PI3K inhibitor, induces the localization of 
p27 ${ }^{\mathrm{KIP} 1}$ into the nucleus and increases the CDK2 association with p27 $7^{\mathrm{KIP} 1}$ [52]. Interestingly, trastuzumab downregulates the expression of genes controlling the cell cycle and DNA replication, which their expression can also be downregulated by PI3K inhibitors [67]. Collectively, these results illustrate that the inhibitory effects of trastuzumab on the PI3K/AKT pathway play a critical role in trastuzumab-induced cell cycle arrest.

\section{Trastuzumab and Antibody-Dependent Cell-Mediated Cytotoxicity (ADCC)}

ADCC is one of the main mechanisms of the anti-tumor function of trastuzumab which is mediated by effector immune cells, particularly $\mathrm{CD} 56^{\mathrm{dim}} \mathrm{CD}^{16+} \mathrm{NK}$ cells [79-81]. The binding of fragment crystallizable $\gamma$ receptors (Fc $\gamma$ Rs) to the Fc region of trastuzumab initiates the ADCC process, which ultimately ends in the secretion of perforin and granzymes from immune effector cells [80,82-84]. The binding of Fc $\gamma \mathrm{R}$ to the Fc portion of the antibody mediates the recruitment of tyrosine-protein kinase Syk to the immunoreceptor tyrosine-based activation motif (ITAM), which activates the SOS/RAS/ERK/p38/MAPK signaling pathway $[85,86]$. In addition, Syk mediates the generation of phosphatidylinositol 4, 5-bisphosphate [PI(4,5)P2] via the activation of PI3K. Phospholipase C gamma (PLC $\gamma)$ catalyzes [PI $(4,5) \mathrm{P} 2]$ into diacylglycerol (DAG) and inositol 1,4,5-trisphosphate (InP3). DAG/PKC induces the MAPK pathway and InP3 mediates the $\mathrm{Ca}^{2+}$ release into the cytoplasm from the endoplasmic reticulum (ER) in immune effector cells, which regulates the release of cytoplasmic granules, such as perforin and granzymes $[87,88]$. Perforin forms pores in the plasma membrane and facilitates granzyme diffusion into the cytoplasm of tumor cells, and granzymes trigger apoptosis in tumor cells by inducing caspase activity and DNA fragmentation $[89,90]$. Tumor cell lysis increases tumor antigen presentation in the tumor microenvironment and consequently enhances the activation of antigen-presenting cells and the polarization of T cells [91]. Moreover, studies show that trastuzumab also boosts other immune responses against HER2-positive BC cells. Gall et al. have demonstrated that trastuzumab increases HER2 uptake by dendritic cells (DC) when the cells are co-cultured with SKBR3 and BT474 HER2-positive BC cells. Interestingly, they showed that this process is specifically dependent on Fc $\gamma$ Rs activity of DCs [92].

Tumor cells, regardless of low or high expression levels of HER2, can be coated, albeit to different extents, by antibodies and destroyed eventually in early or late stages of disease $[93,94]$. However, HER2 overexpression in tumor cell membranes maximizes the ADCC activity [37]. It has been shown that several factors can affect the efficacy of trastuzumab-induced ADCC. For example, the inhibition of EGFR endocytosis, followed by increasing the exposure of the cells to the monoclonal antibody, enhances the ADCC efficacy [95]. Furthermore, low sensitivity to the perforin/granzyme apoptosis pathway makes the tumor cells resistant to the trastuzumab-mediated ADCC [96]. Moreover, single nucleotide polymorphism (SNP) in Fc $\gamma$ Rs has been suggested to be served as a biomarker in the prediction of BC patients' response to Fc-mediated ADCC [97,98]. The modification of anti-HER2 monoclonal antibodies' Fc region to enhance the affinity of the Fc region toward mutant Fc $\gamma$ Rs can be considered as a treatment strategy to increase trastuzumab-induced ADCC in patients with Fc receptor polymorphisms [99].

\section{Trastuzumab and HER2 Isoforms}

The p95HER2 is an amino terminally truncated membrane-bound fragment which is generated from the cleavage of the extracellular domain (ECD) of full length $\sim 185 \mathrm{kDa}$ HER2. The p95HER2 can be generated through proteinases including A disintegrin and metalloproteinases (ADAM)s and matrix metalloproteinases (MMP)s, or alternative internal translation of HER2 mRNA [100,101]. p95HER2/611 carboxyl-terminal fragments (CTF) (100 to 115-kDa) and p95HER2/648CTF (95 to 100-kDa) are two truncated forms of HER2 which are generated from different translation initiation codons [101]. p95HER2 overexpression is associated with poor prognosis and trastuzumab resistance in patients with aggressive BC [102]. p95HER2, especially p95HER2/611CTF, has been shown to have enhanced homodimerization ability and higher tyrosine kinase activity [103-105]. 
Therefore, p95HER2 overexpression leads to the continuous activation of PI3K/AKT and MAPK signaling pathways in BC cells [103-105]. Trastuzumab has been shown to prevent MMP-mediated HER2 shedding, thereby inhibiting p95HER2-regulated downstream signaling pathways like PI3K/AKT [106,107]. However, high expression levels of p95HER2 make the cells resistant to trastuzumab as it cannot bind to p95HER2 due to ECD loss [103]. Parra-Palau et al. showed that the treatment of p95HER2/611CTF-positive breast tumors with doxorubicin makes the tumors sensitive to trastuzumab [108]. Moreover, studies have also focused on using tyrosine kinase inhibitors (TKIs) (e.g., lapatinib) to overcome trastuzumab resistance in BC cells. For example, it has been reported that lapatinib as a dual TKI of HER2 and EGFR inhibits p95HER2 activity and its downstream AKT pathway in BC cells [103]. Heat shock protein 90 (HSP90) overexpression has been shown to contribute to the metastasis of BC cells and poor prognosis in BC patients $[109,110]$. Interestingly, HSP90 inhibitors destabilize p95HER2 and activate apoptosis in trastuzumabresistant p95HER2-positive BC cells [111]. It has been demonstrated that other isoforms of HER2 also affect the trastuzumab mode of action. For example, Castiglioni et al. have shown that the deletion of exon 16 of wild-type HER2 produces an HER2 isoform with a shorter ECD [112]. They found that exon-16-deleted HER2 has a lower binding affinity for trastuzumab compared to wild-type HER2 in HEK-293 cells transfected with wild-type and exon-16-deleted HER2 [112]. However, the same group later reported that trastuzumab suppresses the mammary tumor growth and metastasis more efficiently in transgenic mice expressing the exon-16-deleted isoform of human HER2 compared to transgenic mice expressing wild-type human HER2 [113]. In addition, they showed that the expression of the exon-16-deleted isoform of HER2 is positively correlated with Src activation. Interestingly, clinical results demonstrated that trastuzumab significantly decreases the relapse rate in patients with breast tumors expressing high levels of the exon-16-deleted isoform of HER2 and phosphorylated-Src [113]. Palladini et al. have revealed that the expression of wild-type HER2 or exon-16-deleted isoform of HER2 affects the tumor vasculature [114]. They showed that breast tumors expressing wild-type HER2 form few large vessels which negatively impact drug delivery to the tumor. On the other hand, the exon-16-deleted isoform of HER2 induces the formation of many small vessels which facilitates the drug delivery to the tumor and improves the treatment efficiency.

\section{Mechanisms of Resistance to Trastuzumab}

Clinical results show that two-thirds of the patients do not respond to trastuzumab and patients who initially responded subsequently develop resistance to this therapy [115]. To date, several mechanisms have been proposed to explain how BC cells are resistant, or develop resistance, to trastuzumab treatment. Activating mutations in the $\mathrm{p} 110 \alpha$ subunit of PI3K and/or inactivating mutations in PTEN play a crucial role in trastuzumab resistance through persistent activation of the PI3K/AKT signaling pathway $[21,116,117]$. In addition, some BC cells express truncated HER2, lacking ECD, preventing trastuzumab binding $[103,118]$. Furthermore, hyperactivation of other tyrosine kinase receptors, such as insulin-like growth factor-I receptor (IGF-IR), compensates for the inhibition of HER2 downstream signaling pathway by trastuzumab [119].

Trastuzumab monotherapy is not the current standard of care, and combinational therapies are administered in attempts to overcome the intrinsic or acquired resistance to trastuzumab. Three different groups of drugs are administered in combinational therapies to increase the efficacy of trastuzumab: (1) trastuzumab-modified or -conjugated drugs. For instance, trastuzumab emtansine (T-DM1) is a conjugated trastuzumab and highly toxic drug derivative of maytansine-1 (DM1) [120]. T-DM1 has been shown to improve clinical outcomes of HER2-positive BC patients [121,122]. (2) Antibodies targeting other domains of HER2 (e.g., pertuzumab) and/or other HER receptors (e.g., patritumab targeting HER3). NEOSPHERE clinical trial results showed that the rate of pathological complete response ( $\mathrm{PCR}$ ) was higher for HER2 positive BC patients treated with a combination of pertuzumab, trastuzumab, and docetaxel compared to patients treated with trastuzumab 
and docetaxel [123]. (3) TKIs. For example, lapatinib significantly improves the clinical outcomes of combinational therapy of trastuzumab and aromatase inhibitors in HER2-positive BC patients. [124].

\section{Conclusions and Perspective}

In this review, we scrutinized the effects of trastuzumab on HER2 receptors' functions from HER2 dimerization to HER2-mediated downstream signaling pathways, which are summarized in Figure 3 and Table 1. Generally, four different conditions, including treatment time duration, BC cell types, absence or presence of various HER-specific ligands, and different in vitro and in vivo models affect the mode of action of trastuzumab. This should be considered when interpreting the mechanism of action of trastuzumab. However, regardless of the experimental conditions, the findings strongly suggest that trastuzumab inhibits AKT phosphorylation and arrests the cell cycle through AKT inhibition. Moreover, it is well-documented that trastuzumab significantly activates the ADCC process against the HER2-overexpressed BC tumors. Therefore, the future clinical and experimental studies should focus on the significance of mechanisms through which trastuzumab inhibits AKT phosphorylation, including HER2/HER3/PI3K/AKT and HER2/SRC/PTEN/AKT signaling axes in both resistant and sensitive HER2-positive breast tumors. In addition, further studies on these signaling pathways would help us to have better understanding about the acquired trastuzumab resistance mechanisms. Such studies would benefit us to design novel combination therapies to not only improve the efficacy of trastuzumab, but also overcome the resistance to this drug. Moreover, more studies should be carried out to boost the trastuzumab-activated ADCC process by either modifying the Fc portion of trastuzumab or increasing the activity of human immune effector cells involved in ADCC process.

Table 1. The summary of trastuzumab mechanisms of action based on in vitro evidence.

\begin{tabular}{|c|c|c|c|c|}
\hline Mechanism of Action & Finding & Experimental Model & Method & Reference \\
\hline \multirow{2}{*}{$\begin{array}{l}\text { Effect of trastuzumab on HER2 } \\
\text { homodimerization }\end{array}$} & \multirow[t]{2}{*}{ Activatory effect } & $\begin{array}{l}\text { CHO cells transfected with HER2 } \\
\text { receptors }\end{array}$ & Cross-linking assay & [26] \\
\hline & & $\begin{array}{l}\text { BT474 and SKBR3 HER2-positive } \\
\text { BC cells }\end{array}$ & FRET * & [16] \\
\hline \multirow{2}{*}{$\begin{array}{l}\text { Effect of trastuzumab on } \\
\text { ligand-dependent HER2 } \\
\text { heterodimerization }\end{array}$} & No effect & $\begin{array}{l}\text { BT474 and SKBR3 HER2-positive } \\
\text { BC cells }\end{array}$ & Co-IP ** & [23] \\
\hline & No effect & SKBR3 HER2-positive BC cells & Co-IP & [24] \\
\hline \multirow{3}{*}{$\begin{array}{l}\text { Effect of trastuzumab on } \\
\text { ligand-independent HER2 } \\
\text { heterodimerization }\end{array}$} & Inhibitory effect & SKBR3 HER2-positive BC cells & $\begin{array}{l}\text { Reversible cross-linking } \\
\text { followed by Co-IP }\end{array}$ & [24] \\
\hline & Inhibitory effect & $\begin{array}{l}\text { SKOV3 HER2-positive ovarian } \\
\text { cancer cells }\end{array}$ & TR-FRET *** & [25] \\
\hline & No effect & $\begin{array}{l}\text { BT474 and SKBR3 HER2-positive } \\
\text { BC cells }\end{array}$ & FRET & [16] \\
\hline $\begin{array}{c}\text { Effect of trastuzumab on HER2 } \\
\text { phosphorylation }\end{array}$ & Activatory effect & $\begin{array}{l}\text { SKBR3 and BT474 HER2-positive } \\
\text { BC cells }\end{array}$ & $\mathrm{WB}^{* * * *}$ & {$[29,31,32]$} \\
\hline $\begin{array}{l}\text { Effect of trastuzumab on HER3 } \\
\text { phosphorylation }\end{array}$ & Inhibitory effect & $\begin{array}{l}\text { SKBR3 and BT474 HER2-positive } \\
\text { BC cells }\end{array}$ & WB & {$[24,29]$} \\
\hline \multirow{3}{*}{$\begin{array}{l}\text { Effect of trastuzumab on HER2 } \\
\text { endocytosis and downregulation }\end{array}$} & Activatory effect & SKBR3 HER2-positive BC cells & $\mathrm{ICC}^{\#}$ and WB & {$[34]$} \\
\hline & Activatory effect & HER2-positive BC tumor samples & IHC \#\# & [36] \\
\hline & No effect & SKBR3 HER2-positive BC cells & ICC and WB & {$[31,38]$} \\
\hline \multirow{4}{*}{$\begin{array}{l}\text { Effect of trastuzumab on MAPK } \\
\text { signaling pathway }\end{array}$} & Inhibitory effect & $\begin{array}{l}\text { SKBR3 and BT474 HER2-positive } \\
\text { BC cells }\end{array}$ & WB & [52] \\
\hline & Inhibitory effect & $\begin{array}{l}\text { NCI-N87 HER2-positive gastric } \\
\text { cell line }\end{array}$ & WB & [53] \\
\hline & Inhibitory effect & $\begin{array}{l}\text { MCF10A cells transfected with } \\
\text { chimeric HER2 and } \\
\text { FK506-binding protein (FKBP) }\end{array}$ & WB & [54] \\
\hline & Activatory effect & $\begin{array}{l}\text { SKBR3 and BT474 HER2-positive } \\
\text { BC cells }\end{array}$ & WB & {$[29,31]$} \\
\hline
\end{tabular}


Table 1. Cont.

\begin{tabular}{|c|c|c|c|c|}
\hline Mechanism of Action & Finding & Experimental Model & Method & Reference \\
\hline \multirow{2}{*}{$\begin{array}{c}\text { Effect of trastuzumab on PI3K/AKT } \\
\text { signaling pathway }\end{array}$} & Inhibitory effect & SKBR3 HER2-positive BC cells & ELISA \#\# & [24] \\
\hline & Inhibitory effect & $\begin{array}{l}\text { SKBR3 and BT474 HER2-positive } \\
\text { BC cells }\end{array}$ & WB & {$[29,52,67]$} \\
\hline Effect of trastuzumab on cell cycle & Inhibitory effect & $\begin{array}{l}\text { SKBR3 and BT474 HER2-positive } \\
\text { BC cells }\end{array}$ & $\begin{array}{c}\text { DNA content } \\
\text { quantification using flow } \\
\text { cytometry }\end{array}$ & {$[30,76]$} \\
\hline \multirow{2}{*}{ Effect of trastuzumab on ADCC } & Activatory effect & $\begin{array}{l}\text { CHO cells transfected with HER2 } \\
\text { receptors }\end{array}$ & $\begin{array}{c}\text { Promega ADCC Bioassay } \\
\text { kit }\end{array}$ & [26] \\
\hline & Activatory effect & SKBR3 HER2-positive BC cells & live-cell imaging & [80] \\
\hline $\begin{array}{l}\text { Effect of trastuzumab on } \\
\text { HER2 cleavage }\end{array}$ & Inhibitory effect & $\begin{array}{l}\text { SKBR3 and BT474 HER2-positive } \\
\text { BC cells }\end{array}$ & WB & [107] \\
\hline
\end{tabular}

${ }^{*}$ Fluorescence resonance energy transfer, ${ }^{* *}$ Co-immunoprecipitation, ${ }^{* * *}$ Time-resolved fluorescence resonance energy transfer, ${ }^{* * *}$ Western blot, " Immunocytochemistry, \#\# Immunohistochemistry, "\#\#" Enzyme-linked immunosorbent assay.

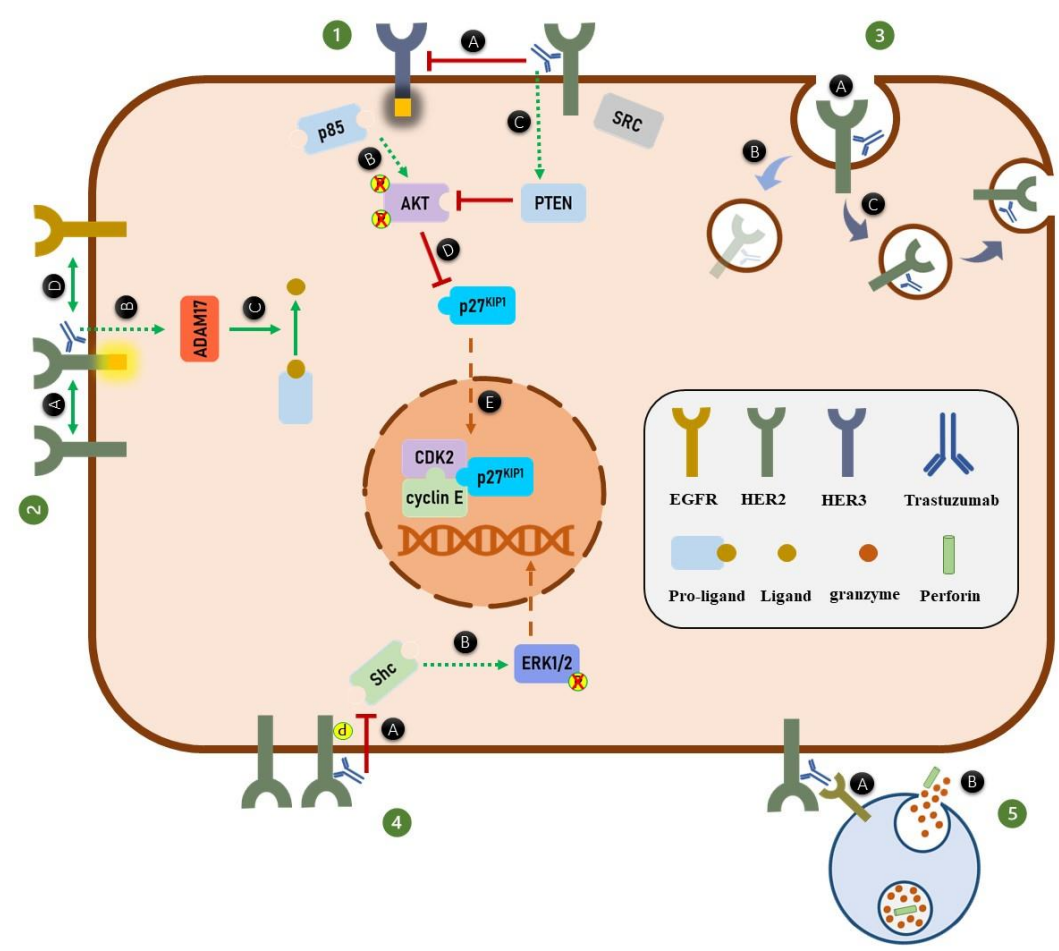

Figure 3. Trastuzumab mechanisms of action. (1) Binding of trastuzumab to HER2 receptors inhibits (A) the ligand-independent HER2-HER3 heterodimer formation, HER3 phosphorylation, and ultimately association of p85 to HER3 receptors. (B) Inhibition of PI3K complex formation inhibits AKT phosphorylation. Moreover, (C) trastuzumab inhibits AKT phosphorylation through activation of PTEN phosphatase activity. (D) Inhibition of AKT phosphorylation, activates $\mathrm{p} 27^{\mathrm{KIP} 1}$ protein. (E) The activated p27 ${ }^{\mathrm{KIP} 1}$ enters the nucleus and arrests the cell cycle through suppressing the function of CDK2/cyclin E complex. (2) Trastuzumab increases HER2 phosphorylation by (A) inducing the HER2 homodimer formation, (B) increasing the expression of ADAM17, which (C) subsequently increases the HER-specific ligand production. (D) Elevation of the HER-specific ligands production from pro-ligands enhances the HER2 heterodimer formation. (3) Binding of trastuzumab to HER2 receptors (A) induces HER2 internalization. The internalized HER2 can be either (B) degraded or (C) recycled to the cell membrane. (4) Trastuzumab through (A) unknown mechanism dissociate Shc from HER2 homodimers which (B) ultimately inhibits ERK1/2 phosphorylation. (5) Trastuzumab induces the ADCC process. (A) Fc region of trastuzumab is recognized by Fc $\gamma$ Rs of immune effector cells like NK cells. (B) Binding of Fc portion of antibody to the Fc $\gamma$ Rs activates downstream signaling pathways in immune effector cells which results in secretion of perforin and granzymes. The granzymes can induce apoptosis in targeted tumor cells. 
Author Contributions: Conceptualization: H.M.; Writing-original draft preparation: H.M., M.H.S., A.M.; Writing—review and editing: W.-S.C. and Z.W.; Supervision: Z.W. All authors have read and agreed to the published version of the manuscript.

Funding: This research has been funded by the grant from Canadian Institutes of Health Research (CIHR): grant \#RES0030993 and the generous support of the Stollery Children's Hospital Foundation through the Women and Children's Health Research Institute.

Conflicts of Interest: The authors declare no conflict of interest.

\section{References}

1. Schechter, A.L.; Stern, D.F.; Vaidyanathan, L.; Decker, S.J.; Drebin, J.A.; Greene, M.I.; Weinberg, R.A. The neu oncogene: An erb-B-related gene encoding a 185,000-Mr tumour antigen. Nat. Cell Biol. 1984, 312, 513-516. [CrossRef] [PubMed]

2. Coussens, L.; Yang-Feng, T.L.; Liao, Y.C.; Chen, E.; Gray, A.; McGrath, J.; Seeburg, P.H.; Libermann, T.; Schlessinger, J.; Francke, U.; et al. Tyrosine kinase receptor with extensive homology to EGF receptor shares chromosomal location with neu oncogene. Science 1985, 230, 1132-1139. [CrossRef]

3. Drebin, J.A.; Link, V.C.; Weinberg, R.A.; Greene, M.I. Inhibition of tumor growth by a monoclonal antibody reactive with an oncogene-encoded tumor antigen. Proc. Natl. Acad. Sci. USA 1986, 83, 9129-9133. [CrossRef]

4. Hudziak, R.M.; Schlessinger, J.; Ullrich, A. Increased expression of the putative growth factor receptor p185HER2 causes transformation and tumorigenesis of NIH 3 T3 cells. Proc. Natl. Acad. Sci. USA 1987, 84, 7159-7163. [CrossRef]

5. Slamon, D.J.; Clark, G.M.; Wong, S.G.; Levin, W.J.; Ullrich, A.; McGuire, W.L. Human breast cancer: Correlation of relapse and survival with amplification of the HER-2/neu oncogene. Science 1987, 235, 177-182. [CrossRef] [PubMed]

6. Hudziak, R.M.; Lewis, G.D.; Winget, M.; Fendly, B.M.; Shepard, H.M.; Ullrich, A. p185HER2 monoclonal antibody has antiproliferative effects in vitro and sensitizes human breast tumor cells to tumor necrosis factor. Mol. Cell. Biol. 1989, 9, 1165-1172. [CrossRef] [PubMed]

7. Carter, P.; Presta, L.; Gorman, C.M.; Ridgway, J.B.; Henner, D.; Wong, W.L.; Rowland, A.M.; Kotts, C.; Carver, M.E.; Shepard, H.M. Humanization of an anti-p185HER2 antibody for human cancer therapy. Proc. Natl. Acad. Sci. USA 1992, 89, 4285-4289. [CrossRef]

8. Slamon, D.J.; Leyland-Jones, B.; Shak, S.; Fuchs, H.; Paton, V.; Bajamonde, A.; Fleming, T.; Eiermann, W.; Wolter, J.; Pegram, M.; et al. Use of Chemotherapy plus a Monoclonal Antibody against HER2 for Metastatic Breast Cancer That Overexpresses HER. N. Engl. J. Med. 2001, 344, 783-792. [CrossRef]

9. Sawyers, C.L. Herceptin: A First Assault on Oncogenes that Launched a Revolution. Cell 2019, 179, 8-12. [CrossRef]

10. Woelderink, A.; Ibarreta, D.; Hopkins, M.M.; Rodríguez-Cerezo, E. The current clinical practice of pharmacogenetic testing in Europe: TPMT and HER2 as case studies. Pharm. J. 2005, 6, 3-7. [CrossRef]

11. Citri, A.; Yarden, Y. EGF-ERBB signalling: Towards the systems level. Nat. Rev. Mol. Cell Biol. 2006, 7, 505-516. [CrossRef] [PubMed]

12. Kovacs, E.; Zorn, J.A.; Huang, Y.; Barros, T.; Kuriyan, J. A Structural Perspective on the Regulation of the Epidermal Growth Factor Receptor. Annu. Rev. Biochem. 2015, 84, 739-764. [CrossRef]

13. Yarden, Y.; Sliwkowski, M.X. Untangling the ErbB signalling network. Nat. Rev. Mol. Cell Biol. 2001, 2, 127-137. [CrossRef]

14. Nami, B.; Maadi, H.; Wang, Z. Mechanisms Underlying the Action and Synergism of Trastuzumab and Pertuzumab in Targeting HER2-Positive Breast Cancer. Cancers 2018, 10, 342. [CrossRef]

15. Cho, H.-S.; Mason, K.; Ramyar, K.X.; Stanley, A.M.; Gabelli, S.; Denney, D.W.; Leahy, D.J. Structure of the extracellular region of HER2 alone and in complex with the Herceptin Fab. Nat. Cell Biol. 2003, 421, 756-760. [CrossRef] [PubMed]

16. Diermeier, S.; Horváth, G.; Knuechel-Clarke, R.; Hofstaedter, F.; Szöllősi, J.; Brockhoff, G. Epidermal growth factor receptor coexpression modulates susceptibility to Herceptin in HER2/neu overexpressing breast cancer cells via specific erbB-receptor interaction and activation. Exp. Cell Res. 2005, 304, 604-619. [CrossRef]

17. Ono, M.; Kuwano, M. Molecular Mechanisms of Epidermal Growth Factor Receptor (EGFR) Activation and Response to Gefitinib and Other EGFR-Targeting Drugs. Clin. Cancer Res. 2006, 12, 7242-7251. [CrossRef]

18. Wang, Z. ErbB Receptors and Cancer. Methods Mol. Biol. 2017, 1652, 3-35. [CrossRef] [PubMed]

19. Wallasch, C.; Weiss, F.U.; Niederfellner, G.; Jallal, B.; Issing, W.; Ullrich, A. Heregulin-dependent regulation of HER2/neu oncogenic signaling by heterodimerization with HER3. EMBO J. 1995, 14, 4267-4275. [CrossRef] [PubMed]

20. Hellyer, N.; Cheng, K.; Koland, J. ErbB3 (HER3) interaction with the p85 regulatory subunit of phosphoinositide 3-kinase. Biochem. J. 1998, 333, 757-763. [CrossRef]

21. Nagata, Y.; Lan, K.-H.; Zhou, X.; Tan, M.; Esteva, F.; Sahin, A.A.; Klos, K.S.; Li, P.; Monia, B.P.; Nguyen, N.T.; et al. PTEN activation contributes to tumor inhibition by trastuzumab, and loss of PTEN predicts trastuzumab resistance in patients. Cancer Cell 2004, 6, 117-127. [CrossRef]

22. Ruiz-Saenz, A.; Dreyer, C.; Campbell, M.R.; Steri, V.; Gulizia, N.; Moasser, M.M.; Gulizia, N.P. HER2 Amplification in Tumors Activates PI3K/Akt Signaling Independent of HER3. Cancer Res. 2018, 78, 3645-3658. [CrossRef]

23. Yu, X.; Wang, L.; Shen, Y.; Wang, C.; Zhang, Y.; Meng, Y.; Yang, Y.; Liang, B.; Zhou, B.; Wang, H.; et al. Targeting EGFR/HER2 heterodimerization with a novel anti-HER2 domain II/III antibody. Mol. Immunol. 2017, 87, 300-307. [CrossRef] [PubMed] 
24. Junttila, T.T.; Akita, R.W.; Parsons, K.; Fields, C.; Phillips, G.D.L.; Friedman, L.S.; Sampath, D.; Sliwkowski, M.X. LigandIndependent HER2/HER3/PI3K Complex Is Disrupted by Trastuzumab and Is Effectively Inhibited by the PI3K Inhibitor GDC-0941. Cancer Cell 2009, 15, 429-440. [CrossRef]

25. Gaborit, N.; Larbouret, C.; Vallaghe, J.; Peyrusson, F.; Bascoul-Mollevi, C.; Crapez, E.; Azria, D.; Chardès, T.; Poul, M.-A.; Mathis, G.; et al. Time-resolved Fluorescence Resonance Energy Transfer (TR-FRET) to Analyze the Disruption of EGFR/HER2 Dimers. J. Biol. Chem. 2011, 286, 11337-11345. [CrossRef]

26. Maadi, H.; Nami, B.; Tong, J.; Li, G.; Wang, Z. The effects of trastuzumab on HER2-mediated cell signaling in CHO cells expressing human HER2. BMC Cancer 2018, 18, 1-14. [CrossRef] [PubMed]

27. Colagar, A.H.; Amjadi, O.; Valadan, R.; Rafiei, A. Minimal HER1 and HER2 expressions in CHO and HEK-293 cells cause them appropriate negative cells for HERs-related studies. Res. Mol. Med. 2013, 1, 6-12. [CrossRef]

28. Hatakeyama, M.; Yumoto, N.; Yu, X.; Shirouzu, M.; Yokoyama, S.; Konagaya, A. Transformation potency of ErbB heterodimer signaling is determined by B-Raf kinase. Oncogene 2004, 23, 5023-5031. [CrossRef] [PubMed]

29. Dokmanovic, M.; Wu, Y.; Shen, Y.; Chen, J.; Hirsch, D.S.; Wu, W.J. Trastuzumab-induced recruitment of Csk-homologous kinase (CHK) to ErbB2 receptor is associated with ErbB2-Y1248 phosphorylation and ErbB2 degradation to mediate cell growth inhibition. Cancer Biol. Ther. 2014, 15, 1029-1041. [CrossRef]

30. Diermeier-Daucher, S.; Breindl, S.; Buchholz, S.; Ortmann, O.; Brockhoff, G. Modular anti-EGFR and anti-Her2 targeting of SKBR-3 and BT474 breast cancer cell lines in the presence of ErbB receptor-specific growth factors. Cytom. Part A 2011, 79, 684-693. [CrossRef]

31. Bagnato, P.; Castagnino, A.; Cortese, K.; Bono, M.; Grasso, S.; Bellese, G.; Daniele, T.; Lundmark, R.; Defilippi, P.; Castagnola, P.; et al. Cooperative but distinct early co-signaling events originate from ERBB2 and ERBB1 receptors upon trastuzumab treatment in breast cancer cells. Oncotarget 2017, 8, 60109-60122. [CrossRef] [PubMed]

32. Gijsen, M.; King, P.; Perera, T.; Parker, P.; Harris, A.; Larijani, B.; Kong, A. HER2 Phosphorylation Is Maintained by a PKB Negative Feedback Loop in Response to Anti-HER2 Herceptin in Breast Cancer. PLoS Biol. 2010, 8, e1000563. [CrossRef] [PubMed]

33. Blobel, C.P. ADAMs: Key components in EGFR signalling and development. Nat. Rev. Mol. Cell Biol. 2005, 6, 32-43. [CrossRef] [PubMed]

34. Dokmanovic, M.; Hirsch, D.S.; Shen, Y.; Wu, W.J. Rac1 contributes to trastuzumab resistance of breast cancer cells: Rac1 as a potential therapeutic target for the treatment of trastuzumab-resistant breast cancer. Mol. Cancer Ther. 2009, 8, 1557-1569. [CrossRef]

35. Di Cara, G.; Marengo, G.; Albanese, N.N.; Marabeti, M.R.; Musso, R.; Cancemi, P.; Pucci-Minafra, I. Proteomic profiling of Trastuzumab (Herceptin(R))-sensitive and -resistant SKBR-3 breast cancer cells. Anticancer. Res. 2013, 33, 489-503.

36. Milella, M.; Trisciuoglio, D.; Bruno, T.; Ciuffreda, L.; Mottolese, M.; Cianciulli, A.; Cognetti, F.; Zangemeister-Wittke, U.; Del Bufalo, D.; Zupi, G. Trastuzumab Down-Regulates Bcl-2 Expression and Potentiates Apoptosis Induction by Bcl-2/Bcl-XL Bispecific Antisense Oligonucleotides in HER-2Gene-Amplified Breast Cancer Cells. Clin. Cancer Res. 2004, 10, 7747-7756. [CrossRef] [PubMed]

37. Scaltriti, M.; Verma, C.; Guzman, M.; Jimenez, J.; Parra, J.L.; Pedersen, K.; Smith, D.J.; Landolfi, S.; Cajal, S.R.Y.; Arribas, J.; et al. Lapatinib, a HER2 tyrosine kinase inhibitor, induces stabilization and accumulation of HER2 and potentiates trastuzumabdependent cell cytotoxicity. Oncogene 2008, 28, 803-814. [CrossRef]

38. Austin, C.D.; De Mazière, A.M.; Pisacane, P.I.; Van Dijk, S.M.; Eigenbrot, C.; Sliwkowski, M.X.; Klumperman, J.; Scheller, R.H. Endocytosis and Sorting of ErbB2 and the Site of Action of Cancer Therapeutics Trastuzumab and Geldanamycin. Mol. Biol. Cell 2004, 15, 5268-5282. [CrossRef]

39. Mohsin, S.K.; Weiss, H.L.; Gutierrez, M.C.; Chamness, G.C.; Schiff, R.; DiGiovanna, M.P.; Wang, C.-X.; Hilsenbeck, S.G.; Osborne, C.K.; Allred, D.C.; et al. Neoadjuvant Trastuzumab Induces Apoptosis in Primary Breast Cancers. J. Clin. Oncol. 2005, 23, 2460-2468. [CrossRef]

40. Pereira, P.; Sharma, S.K.; Carter, L.; Edwards, K.J.; Pourat, J.; Ragupathi, A.; Janjigian, Y.Y.; Durack, J.C.; Lewis, J.S. Caveolin-1 mediates cellular distribution of HER2 and affects trastuzumab binding and therapeutic efficacy. Nat. Commun. 2018, 9, 1-13. [CrossRef]

41. Korzeniecki, C.; Priefer, R. Targeting KRAS mutant cancers by preventing signaling transduction in the MAPK pathway. Eur. J. Med. Chem. 2021, 211, 113006. [CrossRef]

42. Soares-Silva, M.C.; Diniz, F.F.; Gomes, G.N.; Ebahia, D. The Mitogen-Activated Protein Kinase (MAPK) Pathway: Role in Immune Evasion by Trypanosomatids. Front. Microbiol. 2016, 7, 183. [CrossRef] [PubMed]

43. Fang, J.Y.; Richardson, B.C. The MAPK signalling pathways and colorectal cancer. Lancet Oncol. 2005, 6, 322-327. [CrossRef]

44. Braicu, C.; Buse, M.; Busuioc, C.; Drula, R.; Gulei, D.; Raduly, L.; Rusu, A.; Irimie, A.; Atanasov, A.G.; Slaby, O.; et al. A Comprehensive Review on MAPK: A Promising Therapeutic Target in Cancer. Cancers 2019, 11, 1618. [CrossRef]

45. Owens, D.M.; Keyse, S.M. Differential regulation of MAP kinase signalling by dual-specificity protein phosphatases. Oncogene 2007, 26, 3203-3213. [CrossRef] [PubMed]

46. Kato, Y.; Tapping, R.I.; Huang, S.; Watson, M.H.; Ulevitch, R.J.; Lee, J.-D. Bmk1/Erk5 is required for cell proliferation induced by epidermal growth factor. Nat. Cell Biol. 1998, 395, 713-716. [CrossRef]

47. Drew, B.A.; Burow, M.E.; Beckman, B.S. MEK5/ERK5 pathway: The first fifteen years. Biochim. Biophys. Acta (BBA)-Bioenergy 2012, 1825, 37-48. [CrossRef] [PubMed] 
48. Song, H.; Jin, X.; Lin, J. Stat3 upregulates MEK5 expression in human breast cancer cells. Oncogene 2004, 23, 8301-8309. [CrossRef] [PubMed]

49. Nakaoka, Y.; Nishida, K.; Fujio, Y.; Izumi, M.; Terai, K.; Oshima, Y.; Sugiyama, S.; Matsuda, S.; Koyasu, S.; Yamauchi-Takihara, K.; et al. Activation of gp130 transduces hypertrophic signal through interaction of scaffolding/docking protein Gab1 with tyrosine phosphatase SHP2 in cardiomyocytes. Circ. Res. 2003, 93, 221-229. [CrossRef] [PubMed]

50. Liu, P.; Wang, Y.; Li, X. Targeting the untargetable KRAS in cancer therapy. Acta Pharm. Sin. B 2019, 9, 871-879. [CrossRef]

51. Guo, Y.; Pan, W.; Liu, S.; Shen, Z.; Xu, Y.; Hu, L. ERK/MAPK signalling pathway and tumorigenesis (Review). Exp. Ther. Med. 2020, 19, 1997-2007. [CrossRef] [PubMed]

52. Yakes, F.M.; Chinratanalab, W.; Ritter, C.A.; King, W.; Seelig, S.; Arteaga, C.L. Herceptin-induced inhibition of phosphatidylinositol3 kinase and Akt Is required for antibody-mediated effects on p27, cyclin D1, and antitumor action. Cancer Res. 2002, 62, $4132-4141$. [PubMed]

53. Wang, C.; Wang, L.; Yu, X.; Zhang, Y.; Meng, Y.; Wang, H.; Yang, Y.; Gao, J.; Wei, H.; Zhao, J.; et al. Combating acquired resistance to trastuzumab by an anti-ErbB2 fully human antibody. Oncotarget 2017, 8, 42742-42751. [CrossRef] [PubMed]

54. Ghosh, R.; Narasanna, A.; Wang, S.E.; Liu, S.; Chakrabarty, A.; Balko, J.M.; González-Angulo, A.M.; Mills, G.B.; Penuel, E.; Winslow, J.; et al. Trastuzumab Has Preferential Activity against Breast Cancers Driven by HER2 Homodimers. Cancer Res. 2011, 71, 1871-1882. [CrossRef] [PubMed]

55. Sims, A.H.; Zweemer, A.J.; Nagumo, Y.; Faratian, D.; Muir, M.; Dodds, M.; Um, I.; Kay, C.; Hasmann, M.; Harrison, D.J.; et al. Defining the molecular response to trastuzumab, pertuzumab and combination therapy in ovarian cancer. Br. J. Cancer 2012, 106, 1779-1789. [CrossRef]

56. Dubska, L.; Andera, L.; Sheard, M.A. HER2 signaling downregulation by trastuzumab and suppression of the PI3K/Akt pathway: An unexpected effect on TRAIL-induced apoptosis. FEBS Lett. 2005, 579, 4149-4158. [CrossRef]

57. Delord, J.-P.; Quideau, S.; Rochaix, P.; Caselles, O.; Couderc, B.; Hennebelle, I.; Courbon, F.; Canal, P.; Allal, B.C. Trastuzumab induced in vivo tissue remodelling associated in vitro with inhibition of the active forms of AKT and PTEN and RhoB induction in an ovarian carcinoma model. Br. J. Cancer 2010, 103, 61-72. [CrossRef]

58. Watanabe, S.; Yonesaka, K.; Tanizaki, J.; Nonagase, Y.; Takegawa, N.; Haratani, K.; Kawakami, H.; Hayashi, H.; Takeda, M.; Tsurutani, J.; et al. Targeting of the HER2/HER3 signaling axis overcomes ligand-mediated resistance to trastuzumab in HER2-positive breast cancer. Cancer Med. 2019, 8, 1258-1268. [CrossRef]

59. Carmona, F.J.; Montemurro, F.; Kannan, S.; Rossi, V.; Verma, C.; Baselga, J.; Scaltriti, M. AKT signaling in ERBB2-amplified breast cancer. Pharmacol. Ther. 2016, 158, 63-70. [CrossRef]

60. Nicholson, K.M.; Anderson, N.G. The protein kinase B/Akt signalling pathway in human malignancy. Cell. Signal. 2002, 14, 381-395. [CrossRef]

61. Vara, J.; Ángel, F.; Casado, E.; De Castro, J.; Cejas, P.; Iniesta, C.B.; González-Barón, M. PI3K/Akt signalling pathway and cancer. Cancer Treat. Rev. 2004, 30, 193-204. [CrossRef]

62. Soltoff, S.P.; Carraway, K.L.; Prigent, S.A.; Gullick, W.G.; Cantley, L.C. ErbB3 is involved in activation of phosphatidylinositol 3-kinase by epidermal growth factor. Mol. Cell. Biol. 1994, 14, 3550-3558. [CrossRef] [PubMed]

63. Pinkas-Kramarski, R.; Soussan, L.; Waterman, H.; Levkowitz, G.; Alroy, I.; Klapper, L.; Lavi, S.; Seger, R.; Ratzkin, B.J.; Sela, M.; et al. Diversification of Neu differentiation factor and epidermal growth factor signaling by combinatorial receptor interactions. EMBO J. 1996, 15, 2452-2467. [CrossRef] [PubMed]

64. Martini, M.; De Santis, M.C.; Braccini, L.; Gulluni, F.; Hirsch, E. PI3K/AKT signaling pathway and cancer: An updated review. Ann. Med. 2014, 46, 372-383. [CrossRef] [PubMed]

65. Yang, J.; Cron, P.; Good, V.M.; Thompson, V.; Hemmings, B.A.; Barford, D. Crystal structure of an activated Akt/Protein Kinase B ternary complex with GSK3-peptide and AMP-PNP. Nat. Genet. 2002, 9, 940-944. [CrossRef] [PubMed]

66. Naderali, E.; Khaki, A.A.; Rad, J.S.; Ali-Hemmati, A.; Rahmati, M.; Charoudeh, H.N. Regulation and modulation of PTEN activity. Mol. Biol. Rep. 2018, 45, 2869-2881. [CrossRef]

67. Le, X.-F.; Lammayot, A.; Gold, D.; Lu, Y.; Mao, W.; Chang, T.; Patel, A.; Mills, G.B.; Bast, R. Genes Affecting the Cell Cycle, Growth, Maintenance, and Drug Sensitivity Are Preferentially Regulated by Anti-HER2 Antibody through Phosphatidylinositol 3-Kinase-AKT Signaling. J. Biol. Chem. 2005, 280, 2092-2104. [CrossRef]

68. Lu, Y.; Yu, Q.; Liu, J.H.; Zhang, J.; Wang, H.; Koul, D.; McMurray, J.S.; Fang, X.; Yung, W.A.; Siminovitch, K.A.; et al. Src Family Protein-tyrosine Kinases Alter the Function of PTEN to Regulate Phosphatidylinositol 3-Kinase/AKT Cascades. J. Biol. Chem. 2003, 278, 40057-40066. [CrossRef]

69. Otto, T.; Sicinski, T.O.P. Cell cycle proteins as promising targets in cancer therapy. Nat. Rev. Cancer 2017, 17, 93-115. [CrossRef] [PubMed]

70. Vermeulen, K.; Van Bockstaele, D.R.; Berneman, Z.N. The cell cycle: A review of regulation, deregulation and therapeutic targets in cancer. Cell Prolif. 2003, 36, 131-149. [CrossRef]

71. Sherr, C.J. Living with or without cyclins and cyclin-dependent kinases. Genes Dev. 2004, 18, 2699-2711. [CrossRef]

72. Trimarchi, J.; Lees, J.A. Sibling rivalry in the E2F family. Nat. Rev. Mol. Cell Biol. 2002, 3, 11-20. [CrossRef]

73. Wander, S.A.; Zhao, D.; Slingerland, J.M. p27: A Barometer of Signaling Deregulation and Potential Predictor of Response to Targeted Therapies. Clin. Cancer Res. 2011, 17, 12-18. [CrossRef] [PubMed] 
74. Vlach, J.; Hennecke, S.; Amati, B. Phosphorylation-dependent degradation of the cyclin-dependent kinase inhibitor p27Kip1. EMBO J. 1997, 16, 5334-5344. [CrossRef] [PubMed]

75. Ishida, N.; Kitagawa, M.; Hatakeyama, S.; Nakayama, K.-I. Phosphorylation at Serine 10, a Major Phosphorylation Site of p27, Increases Its Protein Stability. J. Biol. Chem. 2000, 275, 25146-25154. [CrossRef] [PubMed]

76. Le, X.-F.; Claret, F.-X.; Lammayot, A.; Tian, L.; Deshpande, D.; LaPushin, R.; Tari, A.M.; Bast, R.C. The Role of Cyclin-dependent Kinase Inhibitor p27Kip1 in Anti-HER2 Antibody-induced G1 Cell Cycle Arrest and Tumor Growth Inhibition. J. Biol. Chem. 2003, 278, 23441-23450. [CrossRef] [PubMed]

77. Motti, M.L.; De Marco, C.; Califano, D.; Fusco, A.; Viglietto, G. Akt-dependent T198 phosphorylation of cyclin-dependent kinase inhibitor p27kip1 in breast cancer. Cell Cycle 2004, 3, 1074-1080. [CrossRef]

78. Larrea, M.D.; Wander, S.A.; Slingerland, J. p27 as Jekyll and Hyde: Regulation of cell cycle and cell motility. Cell Cycle 2009, 8, 3455-3461. [CrossRef]

79. Kim, S.; Song, J.; Park, S.; Ham, S.; Paek, K.; Kang, M.; Chae, Y.; Seo, H.; Kim, H.-C.; Flores, M. Drifts in ADCC-related quality attributes of Herceptin ${ }^{\circledR}$ : Impact on development of a trastuzumab biosimilar. MAbs 2017, 9, 704-714. [CrossRef]

80. Tian, X.; Wei, F.; Wang, L.; Yu, W.; Zhang, N.; Zhang, X.; Han, Y.; Yu, J.; Ren, X. Herceptin Enhances the Antitumor Effect of Natural Killer Cells on Breast Cancer Cells Expressing Human Epidermal Growth Factor Receptor-2. Front. Immunol. 2017, 8, 1426. [CrossRef]

81. De Maria, A.; Bozzano, F.; Cantoni, C.; Moretta, L. Revisiting human natural killer cell subset function revealed cytolytic CD56dimCD16+ NK cells as rapid producers of abundant IFN- on activation. Proc. Natl. Acad. Sci. USA 2011, 108, 728-732. [CrossRef]

82. Kute, T.; Stehle, J.J.R.; Ornelles, D.; Walker, N.; Delbono, O.; Vaughn, J.P. Understanding key assay parameters that affect measurements of trastuzumab-mediated ADCC against Her2 positive breast cancer cells. Oncoimmunology 2012, 1, 810-821. [CrossRef] [PubMed]

83. Treffers, L.W.; Van Houdt, M.; Bruggeman, C.W.; Heineke, M.H.; Zhao, X.W.; Van Der Heijden, J.; Nagelkerke, S.Q.; Verkuijlen, P.J.J.H.; Geissler, J.; Lissenberg-Thunnissen, S.; et al. Fc $\gamma$ RIIIb Restricts Antibody-Dependent Destruction of Cancer Cells by Human Neutrophils. Front. Immunol. 2019, 9, 3124. [CrossRef]

84. Wang, W.; Erbe, A.K.; Hank, J.A.; Morris, Z.S.; Sondel, P.M. NK cell-mediated antibody-dependent cellular cytotoxicity in cancer immunotherapy. Front. Immunol. 2015, 6, 368. [CrossRef] [PubMed]

85. Kortum, R.L.; Rouquette-Jazdanian, A.K.; Samelson, L.E. Ras and extracellular signal-regulated kinase signaling in thymocytes and T cells. Trends Immunol. 2013, 34, 259-268. [CrossRef] [PubMed]

86. Khurana, D.; Arneson, L.N.; Schoon, R.A.; Dick, C.J.; Leibson, P.J. Differential Regulation of Human NK Cell-Mediated Cytotoxicity by the Tyrosine Kinase Itk. J. Immunol. 2007, 178, 3575-3582. [CrossRef] [PubMed]

87. Liu, X.-G.; Liu, Y.; Chen, F. Soluble fibrinogen like protein 2 (sFGL2), the novel effector molecule for immunoregulation. Oncotarget 2016, 8, 3711-3723. [CrossRef]

88. Gumbleton, M.; Kerr, W.G. Role of inositol phospholipid signaling in natural killer cell biology. Front. Immunol. 2013, 4, 47. [CrossRef]

89. Lieberman, J. Anatomy of a murder: How cytotoxic T cells and NK cells are activated, develop, and eliminate their targets. Immunol. Rev. 2010, 235, 5-9. [CrossRef]

90. Prager, I.; Liesche, C.; Van Ooijen, H.; Urlaub, D.; Verron, Q.; Sandström, N.; Fasbender, F.; Claus, M.; Eils, R.; Beaudouin, J.; et al. NK cells switch from granzyme B to death receptor-mediated cytotoxicity during serial killing. J. Exp. Med. 2019, 216, $2113-2127$. [CrossRef]

91. Rainone, V.; Martelli, C.; Ottobrini, L.; Biasin, M.; Borelli, M.; Lucignani, G.; Trabattoni, D.; Clerici, M. Immunological Characterization of Whole Tumour Lysate-Loaded Dendritic Cells for Cancer Immunotherapy. PLoS ONE 2016, 11, e0146622. [CrossRef] [PubMed]

92. Gall, V.A.; Philips, A.V.; Qiao, N.; Clise-Dwyer, K.; Perakis, A.A.; Zhang, M.; Clifton, G.T.; Sukhumalchandra, P.; Ma, Q.; Reddy, S.M.; et al. Trastuzumab Increases HER2 Uptake and Cross-Presentation by Dendritic Cells. Cancer Res. 2017, 77, 5374-5383. [CrossRef]

93. Collins, D.M.; O’Donovan, N.; McGowan, P.; O'Sullivan, F.; Duffy, M.J.; Crown, J. Trastuzumab induces antibody-dependent cell-mediated cytotoxicity (ADCC) in HER-2-non-amplified breast cancer cell lines. Ann. Oncol. 2012, 23, 1788-1795. [CrossRef] [PubMed]

94. Petricevic, B.; Laengle, J.; Singer, J.; Sachet, M.; Fazekas, J.; Steger, G.; Bartsch, R.; Jensen-Jarolim, E.; Bergmann, M. Trastuzumab mediates antibody-dependent cell-mediated cytotoxicity and phagocytosis to the same extent in both adjuvant and metastatic HER2/neu breast cancer patients. J. Transl. Med. 2013, 11, 307. [CrossRef] [PubMed]

95. Chew, H.Y.; De Lima, P.O.; Cruz, J.L.G.; Banushi, B.; Echejoh, G.; Hu, L.; Joseph, S.R.; Lum, B.; Rae, J.; O’Donnell, J.S.; et al. Endocytosis Inhibition in Humans to Improve Responses to ADCC-Mediating Antibodies. Cell 2020, 180, 895-914.e27. [CrossRef] [PubMed]

96. Kawaguchi, Y.; Kono, K.; Mizukami, Y.; Mimura, K.; Fujii, H. Mechanisms of escape from trastuzumab-mediated ADCC in esophageal squamous cell carcinoma: Relation to susceptibility to perforin-granzyme. Anticancer. Res. 2009, 29, 2137-2146. 
97. Boero, S.; Morabito, A.; Banelli, B.; Cardinali, B.; Dozin, B.; Lunardi, G.; Piccioli, P.; Lastraioli, S.; Carosio, R.; Salvi, S.; et al. Analysis of in vitro ADCC and clinical response to trastuzumab: Possible relevance of Fc $\gamma$ RIIIA/Fc $\gamma$ RIIA gene polymorphisms and HER-2 expression levels on breast cancer cell lines. J. Transl. Med. 2015, 13, 1-14. [CrossRef]

98. Bournazos, S.; Woof, J.M.; Hart, S.P.; Dransfield, I. Functional and clinical consequences of Fc receptor polymorphic and copy number variants. Clin. Exp. Immunol. 2009, 157, 244-254. [CrossRef]

99. Bang, Y.J.; Giaccone, G.; Im, S.A.; Oh, D.Y.; Bauer, T.M.; Nordstrom, J.L.; Li, H.; Chichili, G.R.; Moore, P.A.; Hong, S.; et al. First-in-human phase 1 study of margetuximab (MGAH22), an Fc-modified chimeric monoclonal antibody, in patients with HER2-positive advanced solid tumors. Ann. Oncol. 2017, 28, 855-861. [CrossRef]

100. Tural, D.; Akar, E.; Mutlu, H.; Kilickap, S. P95 HER2 fragments and breast cancer outcome. Expert Rev. Anticancer Ther. 2014, 14, 1089-1096. [CrossRef]

101. Anido, J.; Scaltriti, M.; Bech-Serra, J.J.; Josefat, B.S.; Todo, F.R.; Baselga, J.; Arribas, J. Biosynthesis of tumorigenic HER2 C-terminal fragments by alternative initiation of translation. EMBO J. 2006, 25, 3234-3244. [CrossRef] [PubMed]

102. Chumsri, S.; Sperinde, J.; Liu, H.; Gligorov, J.; Spano, J.-P.; Antoine, M.; Aspitia, A.M.; Tan, W.; Winslow, J.; Petropoulos, C.J.; et al High p95HER2/HER2 Ratio Associated With Poor Outcome in Trastuzumab-Treated HER2-Positive Metastatic Breast Cancer NCCTG N0337 and NCCTG 98-32-52 (Alliance). Clin. Cancer Res. 2018, 24, 3053-3058. [CrossRef]

103. Scaltriti, M.; Rojo, F.; Ocana, A.; Anido, J.; Guzman, M.; Cortes, J.; Di Cosimo, S.; Matias-Guiu, X.; Cajal, S.R.Y.; Arribas, J.; et al. Expression of p95HER2, a Truncated Form of the HER2 Receptor, and Response to Anti-HER2 Therapies in Breast Cancer. J. Natl. Cancer Inst. 2007, 99, 628-638. [CrossRef] [PubMed]

104. Pedersen, K.; Angelini, P.-D.; Laos, S.; Bach-Faig, A.; Cunningham, M.P.; Ferrer-Ramón, C.; Luque-García, A.; Garcia-Castillo, J.; Parra-Palau, J.L.; Scaltriti, M.; et al. A Naturally Occurring HER2 Carboxy-Terminal Fragment Promotes Mammary Tumor Growth and Metastasis. Mol. Cell. Biol. 2009, 29, 3319-3331. [CrossRef] [PubMed]

105. Arribas, J.; Baselga, J.; Pedersen, K.; Parra-Palau, J.L. p95HER2 and Breast Cancer. Cancer Res. 2011, 71, 1515-1519. [CrossRef] [PubMed]

106. Gajria, D.; Chandarlapaty, S. HER2-amplified breast cancer: Mechanisms of trastuzumab resistance and novel targeted therapies. Expert Rev. Anticancer Ther. 2011, 11, 263-275. [CrossRef] [PubMed]

107. Molina, M.A.; Codony-Servat, J.; Albanell, J.; Rojo, F.; Arribas, J.; Baselga, J. Trastuzumab (herceptin), a humanized anti-Her2 receptor monoclonal antibody, inhibits basal and activated Her2 ectodomain cleavage in breast cancer cells. Cancer Res. 2001, 61, 4744-4749.

108. Parra-Palau, J.L.; Morancho, B.; Peg, V.; Escorihuela, M.; Scaltriti, M.; Vicario, R.; Zacarias-Fluck, M.; Pedersen, K.; Pandiella, A.; Nuciforo, P.; et al. Effect of p95HER2/611CTF on the Response to Trastuzumab and Chemotherapy. J. Natl. Cancer Inst. 2014, 106. [CrossRef]

109. Zagouri, F.; Bournakis, E.; Koutsoukos, K.; Papadimitriou, C.A. Heat Shock Protein 90 (Hsp90) Expression and Breast Cancer. Pharmaceuticals 2012, 5, 1008-1020. [CrossRef]

110. Crouch, B.; Murphy, H.; Belonwu, S.; Martinez, A.; Gallagher, J.; Hall, A.; Soo, M.S.; Lee, M.; Hughes, P.; Haystead, T.; et al. Leveraging ectopic Hsp90 expression to assay the presence of tumor cells and aggressive tumor phenotypes in breast specimens. Sci. Rep. 2017, 7, 1-13. [CrossRef]

111. Chandarlapaty, S.; Scaltriti, M.; Angelini, P.; Ye, Q.; Guzman, M.; Hudis, C.A.; Norton, L.; Solit, D.B.; Arribas, J.; Baselga, J.; et al. Inhibitors of HSP90 block p95-HER2 signaling in Trastuzumab-resistant tumors and suppress their growth. Oncogene 2009, 29, 325-334. [CrossRef]

112. Castiglioni, F.; Tagliabue, E.; Campiglio, M.; Pupa, S.; Balsari, A.; Ménard, S. Role of exon-16-deleted HER2 in breast carcinomas. Endocr. Relat. Cancer 2006, 13, 221-232. [CrossRef]

113. Castagnoli, L.; Iezzi, M.; Ghedini, G.C.; Ciravolo, V.; Marzano, G.; Lamolinara, A.; Zappasodi, R.; Gasparini, P.; Campiglio, M.; Amici, A.; et al. Activated d16HER2 Homodimers and SRC Kinase Mediate Optimal Efficacy for Trastuzumab. Cancer Res. 2014, 74, 6248-6259. [CrossRef]

114. Palladini, A.; Nicoletti, G.; Lamolinara, A.; Dall'Ora, M.; Balboni, T.; Ianzano, M.L.; Laranga, R.; Landuzzi, L.; Giusti, V.; Ceccarelli, C.; et al. HER2 isoforms co-expression differently tunes mammary tumor phenotypes affecting onset, vasculature and therapeutic response. Oncotarget 2017, 8, 54444-54458. [CrossRef]

115. Bartsch, R.; Wenzel, C.; Steger, G.G. Trastuzumab in the management of early and advanced stage breast cancer. Biol. Targets Ther. 2007, 1, 19-31.

116. Berns, K.; Horlings, H.M.; Hennessy, B.T.; Madiredjo, M.; Hijmans, M.; Beelen, K.; Linn, S.C.; Gonzalez-Angulo, A.M.; StemkeHale, K.; Hauptmann, M.; et al. A Functional Genetic Approach Identifies the PI3K Pathway as a Major Determinant of Trastuzumab Resistance in Breast Cancer. Cancer Cell 2007, 12, 395-402. [CrossRef] [PubMed]

117. Serra, V.; Markman, B.; Scaltriti, M.; Eichhorn, P.; Valero, V.; Guzman, M.; Botero, M.L.; Llonch, E.; Atzori, F.; Di Cosimo, S.; et al NVP-BEZ235, a Dual PI3K/mTOR Inhibitor, Prevents PI3K Signaling and Inhibits the Growth of Cancer Cells with Activating PI3K Mutations. Cancer Res. 2008, 68, 8022-8030. [CrossRef] [PubMed]

118. Scott, G.K.; Robles, R.; Park, J.W.; Montgomery, P.A.; Daniel, J.; Holmes, W.E.; Lee, J.; Keller, G.A.; Li, W.L.; Fendly, B.M. A truncated intracellular HER2/neu receptor produced by alternative RNA processing affects growth of human carcinoma cells. Mol. Cell. Biol. 1993, 13, 2247-2257. [CrossRef] 
119. Lu, Y.; Zi, X.; Zhao, Y.; Mascarenhas, D.; Pollak, M. Insulin-Like Growth Factor-I Receptor Signaling and Resistance to Trastuzumab (Herceptin). J. Natl. Cancer Inst. 2001, 93, 1852-1857. [CrossRef]

120. Barok, M.; Joensuu, H.; Isola, J. Trastuzumab emtansine: Mechanisms of action and drug resistance. Breast Cancer Res. 2014, 16, 1-12. [CrossRef]

121. Von Minckwitz, G.; Huang, C.-S.; Mano, M.S.; Loibl, S.; Mamounas, E.P.; Untch, M.; Wolmark, N.; Rastogi, P.; Schneeweiss, A.; Redondo, A.; et al. Trastuzumab Emtansine for Residual Invasive HER2-Positive Breast Cancer. N. Engl. J. Med. 2019, 380, 617-628. [CrossRef]

122. Peddi, P.F.; Hurvitz, S.A. Ado-trastuzumab emtansine (T-DM1) in human epidermal growth factor receptor 2 (HER2)-positive metastatic breast cancer: Latest evidence and clinical potential. Ther. Adv. Med Oncol. 2014, 6, 202-209. [CrossRef] [PubMed]

123. Gianni, L.; Pienkowski, T.; Im, Y.-H.; Roman, L.; Tseng, L.-M.; Liu, M.-C.; Lluch, A.; Staroslawska, E.; Rodríguez, J.R.D.L.H.; Im, S.-A.; et al. Efficacy and safety of neoadjuvant pertuzumab and trastuzumab in women with locally advanced, inflammatory, or early HER2-positive breast cancer (NeoSphere): A randomised multicentre, open-label, phase 2 trial. Lancet Oncol. 2012, 13, 25-32. [CrossRef]

124. Johnston, S.R.; Hegg, R.; Im, S.-A.; Park, I.H.; Burdaeva, O.; Kurteva, G.; Press, M.F.; Tjulandin, S.; Iwata, H.; Simon, S.D.; et al. Phase III, Randomized Study of Dual Human Epidermal Growth Factor Receptor 2 (HER2) Blockade With Lapatinib Plus Trastuzumab in Combination With an Aromatase Inhibitor in Postmenopausal Women With HER2-Positive, Hormone Receptor-Positive Metastatic Breast Cancer: ALTERNATIVE. J. Clin. Oncol. 2018, 36, 741-748. [CrossRef] [PubMed] 